\title{
A Streptomyces sp. NEAU-HV9: Isolation, Identification, and Potential as a Biocontrol Agent against Ralstonia solanacearum of Tomato Plants
}

\author{
Ling Ling ${ }^{1}$, Xiaoyang Han ${ }^{1}$, Xiao Li ${ }^{1}$, Xue Zhang ${ }^{1}$, Han Wang ${ }^{1}$, Lida Zhang ${ }^{1}$, Peng Cao ${ }^{1}$, \\ Yutong $W u^{1}$, Xiangjing Wang ${ }^{1}$, Junwei Zhao ${ }^{1, * \mathbb{D}}$ and Wensheng Xiang ${ }^{1,2, *}$ \\ 1 Key Laboratory of Agricultural Microbiology of Heilongjiang Province, Northeast Agricultural University, \\ No. 59 Mucai Street, Xiangfang District, Harbin 150030, China; LLYNL2621161093@163.com (L.L.); \\ hanxy139251@163.com (X.H.); Lx1244070003@126.com (X.L.); zhangxue_968425@163.com (X.Z.); \\ wanghan507555536@gmail.com (H.W.); yone910310@163.com (L.Z.); cp511@126.com (P.C.); \\ 18103699151@163.com (Y.W.); wangneau2013@163.com (X.W.) \\ 2 State Key Laboratory for Biology of Plant Diseases and Insect Pests, Institute of Plant Protection, \\ Chinese Academy of Agricultural Sciences, Beijing 100193, China \\ * Correspondence: guyan2080@126.com (J.Z.); xiangwensheng@neau.edu.cn (W.X.)
}

Received: 25 October 2019; Accepted: 12 February 2020; Published: 1 March 2020

\begin{abstract}
Ralstonia solanacearum is an important soil-borne bacterial plant pathogen. In this study, an actinomycete strain named NEAU-HV9 that showed strong antibacterial activity against Ralstonia solanacearum was isolated from soil using an in vitro screening technique. Based on physiological and morphological characteristics and $98.90 \%$ of 16 S rRNA gene sequence similarity with Streptomyces panaciradicis $1 \mathrm{MR}-8^{\mathrm{T}}$, the strain was identified as a member of the genus Streptomyces. Tomato seedling and pot culture experiments showed that after pre-inoculation with the strain NEAU-HV9, the disease occurrence of tomato seedlings was effectively prevented for $R$. solanacearum. Then, a bioactivity-guided approach was employed to isolate and determine the chemical identity of bioactive constituents with antibacterial activity from strain NEAU-HV9. The structure of the antibacterial metabolite was determined as actinomycin D on the basis of extensive spectroscopic analysis. To our knowledge, this is the first report that actinomycin D has strong antibacterial activity against $R$. solanacearum with a MIC (minimum inhibitory concentration) of $0.6 \mathrm{mg} \mathrm{L}^{-1}$ $\left(0.48 \mu \mathrm{mol} \mathrm{L}{ }^{-1}\right)$. The in vivo antibacterial activity experiment showed that actinomycin $\mathrm{D}$ possessed significant preventive efficacy against $R$. solanacearum in tomato seedlings. Thus, strain NEAU-HV9 could be used as BCA (biological control agent) against $R$. solanacearum, and actinomycin $\mathrm{D}$ might be a promising candidate for a new antibacterial agent against $R$. solanacearum.
\end{abstract}

Keywords: antibacterial activity; Ralstonia solanacearum; Streptomyces sp. NEAU-HV9; actinomycin D

\section{Introduction}

Tomato is one of the world's most important vegetable crops, with a global annual yield of approximately 160 million tons [1,2]. In China, long term continuous cropping is the main planting practice for tomato, which has led to serious soilborne diseases [3]. Ralstonia solanacearum [4] is an important soilborne bacterial plant pathogen [5]. Bacterial wilt caused by R. solanacearum is a serious and common disease, which reduces the yield of tomato and many other crops in tropical, subtropical, and warm-temperature regions of the world [6]. Because of worldwide distribution and a large host range of more than 200 plant species in 50 families, including pepper, tomato, tobacco, potato, peanut, and banana, this soil bacterium has been recognized as one of the causative agents of bacterial wilt disease and is one of the leading models in pathogenicity [5]. In the absence of host plants, this bacterium can 
be free-living as a saprophyte in the soil or in water [7]. Plant breeding, field sanitation, crop rotation, and use of bactericides have met with only limited success for $R$. solanacearum [8]. Furthermore, pathogenic microbial multi-drug resistance is also increasing. Therefore, new natural resources and antibiotics for suppressing this soilborne disease are needed.

Various recent studies have showed that biological control of bacterial wilt disease could be achieved using antagonistic bacteria [8,9]. The suppressive effect of some antagonistic bacteria on R. solanacearum was reported by Toyota and Kimura [10]. Moreover, the use of antagonistic bacteria to be effective in control of $R$. solanacearum has been proved by Ciampi-Panno et al. under field conditions [8]. Streptomycetes are gaining interest in agriculture as plant growth promoting (PGP) bacteria and/or biological control agents (BCAs) [11,12]. The Streptomyces genus comprises Gram-positive bacteria which show a filamentous form; they can grow in various environments. Several Streptomyces species such as S. aureofaciens, S. avermitilis, S. lividans, S. humidus, S. hygroscopicus, S. lydicus, S. plicatus, S. olivaceoviridis, S. roseoflavus, S. scabies and S. violaceusniger have been used to control soilborne diseases due to their greatly antagonistic activities by production of various antimicrobial substances [13-15].

Actinobacteria are famous for producing a variety of natural bioactive metabolites. Streptomyces is an important source of bioactive compounds among all members of antibiotic production, accounting for two-thirds of commercially available antibiotics [16]. Actinomycins belonging to a family of chromopeptide lactones are produced by various Streptomyces. Among several antibiotics produced by this genus, actinomycins are prominent. More than 20 naturally-occurring actinomycins were isolated and observed to have commonality of two pentapeptidolactone moieties with an actnoyl chromophore [17]; however, they differ in functional and/or positional group. Among actinomycins, actinomycin D has been widely studied and used clinically as an anticancer drug, especially in the treatment of childhood rhabdomyosarcoma, infantile kidney tumors and several other malignant tumors [18,19]. However, no reports have been published on actinomycin D against phytopathogen R. solanacearum.

In the existing protocol for virulence assays, one-month old tomato plantlets are soil-inoculated with the bacterium and wilting symptoms, if any, are observed and recorded. In usual ground work, tomato seeds are sown to obtain seedlings that take 5-6 days to sprout. Seedlings are then transferred to pots containing soil and grown in a greenhouse for about one month. Following this, plants are shifted to a growth chamber where plants are inoculated with the pathogen by soil drench or the stem inoculation method [20,21]. Using this approach, it usually takes 40 days to perform a single virulence assay. The infection achieved in this way is generally not axenic as the soil conditions used are not devoid of other bacterial communities that can colonize the plant during its growth prior to the infection study. Singh et al. [22] described a simple assay to study the pathogenicity of $R$. solanacearum on freshly grown tomato seedlings instead of fully-grown tomato plants. From seed germination to completion of the infection process, the study takes around 15 to 20 days. Pathogenicity due to $R$. solanacearum was also demonstrated when there is no significant plant growth since no mineral/growth inducing factors have been added into the water [23]. Under this same condition, there are reports of the bacterium's survivability without any growth [24]. The death of tomato seedlings was actually occurring due to the presence of $R$. solanacearum in the water. On the basis of the previous study, we have discussed an approach to study biological assays in tomato seedlings.

In this study, a Streptomyces sp., NEAU-HV9, was isolated and showed strong antimicrobial activity against $R$. solanacearum. The taxonomic identity of NEAU-HV9 was determined by a combination of $16 \mathrm{~S}$ rRNA gene sequence analysis with morphological and physiological characteristics. The potential control of actinomycin D produced by the strain NEAU-HV9 against R. solanacearum was also investigated. 


\section{Materials and Methods}

\subsection{Sample Collection}

Soil samples were collected from a field situated in Bama yao Autonomous County, Hechi City, Guangxi zhuang Autonomous Region $\left(24^{\circ} 15^{\prime} \mathrm{N}, 107^{\circ} 26^{\prime} \mathrm{E}\right)$. The collected soil samples were brought to the laboratory in sterile bags and kept at $4^{\circ} \mathrm{C}$ until further analysis. Before isolation of actinomycetes, the soil samples were air-dried at room temperature.

\subsection{Screening and Isolation of Actinomycetes}

The soil sample $(5 \mathrm{~g})$ was mixed with $45 \mathrm{~mL}$ distilled water and followed by an ultrasonic treatment $(160 \mathrm{~W})$ for $3 \mathrm{~min}$. The soil suspension was incubated at $28{ }^{\circ} \mathrm{C}$ and $250 \mathrm{rpm}$ on a rotary shaker for $30 \mathrm{~min}$. Subsequently, the supernatant was collected and subjected to serial dilutions from $10^{-2}$ to $10^{-5}$. Each dilution $(200 \mu \mathrm{L})$ was spread on a plate of humic acid-vitamin (HV) agar [25] supplemented with cycloheximide (50 $\left.\mathrm{mg} \mathrm{L}^{-1}\right)$ and nalidixic acid $\left(20 \mathrm{mg} \mathrm{L}^{-1}\right)$. Colonies were transferred and purified on International Streptomyces Project (ISP) medium 3 [26] and stored for a long time in glycerol suspensions $(20 \%, v / v)$ at $-80{ }^{\circ} \mathrm{C}$ after 14 days of aerobic incubation at $28^{\circ} \mathrm{C}$.

\subsection{Screening of Antagonistic Actinobacteria Strains}

The isolates were screened using the agar well diffusion method, and $R$. solanacearum was used as the indicator bacterium [27]. To further investigate the antibacterial components produced by the isolated cultures, these strains were cultured in ISP 2 medium [26] and the inhibitory activities of the supernatant and cell precipitate were tested. Initially, the isolated cultures were grown in ISP 2 medium and incubated at $28{ }^{\circ} \mathrm{C}$ on a rotary shaker. After 7 days of incubation, the supernatants were obtained by centrifugation at $8000 \mathrm{rpm}$ and $4{ }^{\circ} \mathrm{C}$ for $10 \mathrm{~min}$ and subsequently filtrated with a $0.2 \mu \mathrm{m}$ membrane filter. The cell precipitates were extracted with an equal volume of methanol for

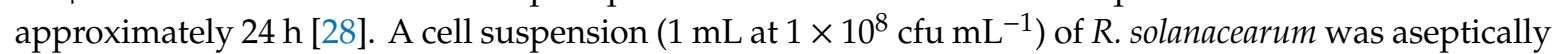
plated onto Bactoagar-glucose (BG) media supplemented with 0.5\% glucose [22]. Supernatant and methanol extracts were collected from each isolate and tested initially for antimicrobial activity against $R$. solanacearum; each well contained $200 \mu \mathrm{L}$ of supernatant or methanol extract. The plates were incubated at $37{ }^{\circ} \mathrm{C}$ for $12 \mathrm{~h}$ to test antibacterial activity. The diameters of inhibition zones were measured by using vernier calipers [29]. The experiments were conducted twice. The isolates that showed activities against tested organisms were collected and maintained. Among the collected isolates, the potential isolate designated as NEAU-HV9 was selected for further studies.

\subsection{Morphological and Biochemical Characteristics of NEAU-HV9}

Morphological characteristics, using cultures grown on ISP 3 medium at $28{ }^{\circ} \mathrm{C}$ for 2 weeks, were observed by light microscopy (Nikon ECLIPSE E200, Nikon Corporation, Tokyo, Japan) and scanning electron microscopy (Hitachi SU8010, Hitachi Co., Tokyo, Japan). Scanning electron microscopy samples were prepared as described by Jin et al. [30]. Cultural characteristics were determined using 2-week cultures grown at $28^{\circ} \mathrm{C}$ on Czapek's agar [31], Bennett's agar [32], Nutrient agar [33], ISP 1 agar and ISP 2-7 media [26]. The color designation of substrate mycelium and aerial mycelium was done with ISCC-NBS (Inter-Society Color Council-National Bureau of Standards) Color Charts Standard Sample No. 2106 [34]. Growth at different temperatures $\left(10{ }^{\circ} \mathrm{C}, 15^{\circ} \mathrm{C}, 18{ }^{\circ} \mathrm{C}, 20^{\circ} \mathrm{C}, 25^{\circ} \mathrm{C}, 28{ }^{\circ} \mathrm{C}\right.$, $32{ }^{\circ} \mathrm{C}, 35^{\circ} \mathrm{C}, 37^{\circ} \mathrm{C}$ and $40^{\circ} \mathrm{C}$ ) was determined on ISP 3 medium after incubation for 14 days. Growth tests for $\mathrm{pH}$ range $(\mathrm{pH}$ 4.0-10.0, at intervals of $1.0 \mathrm{pH}$ unit) using the buffer system described by Zhao et al. [35] and $\mathrm{NaCl}$ tolerance $(0 \%, 1 \%, 2 \%, 3 \%, 4 \%, 5 \%, 6 \%, 7 \%, 8 \%, 9 \%$ and 10\%, w/v) were tested in ISP 2 broth at $28{ }^{\circ} \mathrm{C}$ for 14 days on a rotary shaker. Biochemical testing (decomposition of adenine, casein, hypoxanthine, tyrosine, xanthine and cellulose, hydrolysis of starch, aesculin and gelatin, milk peptonization and coagulation, nitrate reduction and $\mathrm{H}_{2} \mathrm{~S}$ production), the utilization of sole carbon and nitrogen sources were examined as described previously [36,37]. 


\subsection{Phylogenetic Analysis of NEAU-HV9}

Strain NEAU-HV9 was cultured in ISP 2 medium for 3 days at $28^{\circ} \mathrm{C}$ to harvest cells. The genomic DNA was isolated using a Bacteria DNA Kit (TIANGEN Biotech, Co. Ltd., Beijing, China). The universal bacterial primers $27 \mathrm{~F}$ and 1541R were used to carry out PCR amplification of the 16S rRNA gene sequence [38,39]. The purified PCR product cloned into the vector pMD19-T (Takara) and sequenced by using an Applied Biosystems DNA sequencer (model 3730XL, Applied Biosystems Inc., Foster City, California, USA). The almost complete $16 \mathrm{~S}$ rRNA gene sequence (1510 bp) was uploaded to the EzBioCloud server (Available online: https://www.ezbiocloud.net/) [40] to calculate pairwise 16S rRNA gene sequence similarity between strain NEAU-HV9 and related similar species. The phylogenetic tree was reconstructed with neighbor-joining trees [41] using MEGA 7.0 software [42]. The confidence value of branches of the neighbor-joining tree was assessed using bootstrap resampling with 1000 replication [43]. A distance matrix was calculated using Kimura's two-parameter model [44]. All positions containing gaps and missing data were eliminated from the dataset (complete deletion option).

\subsection{Fermentation}

Strain NEAU-HV9 was grown and maintained for 7 days at $28^{\circ} \mathrm{C}$ on ISP 3 medium agar plates. Fermentation involved the generation of a seed culture. The stock culture was transferred into two $250 \mathrm{~mL}$ Erlenmeyer flasks containing $50 \mathrm{~mL}$ of the ISP2 medium and incubated at $28^{\circ} \mathrm{C}$ for $72 \mathrm{~h}$ on a rotary shaker at $250 \mathrm{rpm}$. All of the media were sterilized at $121^{\circ} \mathrm{C}$ for $20 \mathrm{~min}$. The seed culture (5\%) was transferred into 75 flasks $(250 \mathrm{~mL})$ containing $100 \mathrm{~mL}$ of production medium. The production medium was composed of maltodextrin $4 \%$, lactose $4 \%$, yeast extract $0.5 \%$, Mops $2 \%$ at pH 7.2-7.4. The flasks were incubated at $28^{\circ} \mathrm{C}$ for 7 days, shaken at $250 \mathrm{rpm}$. The final $7.5 \mathrm{~L}$ fermentation broth was filtered to separate the supernatant and the mycelial cake. The supernatant was extracted with ethyl acetate three times $(3 \times 2 \mathrm{~L})$, and the mycelial cake was extracted with $\mathrm{MeOH}(3 \mathrm{~L})$. The organic phase was evaporated under reduced pressure at $55^{\circ} \mathrm{C}$ to yield the red crude extract $(5.2 \mathrm{~g})$.

\subsection{Isolation and Purification of Antibacterial Compounds}

Crude extract from the mycelium and supernatant was combined and subjected to silica gel column chromatography (Qingdao Haiyang Chemical Group, Qingdao, China; 100-200 mesh; $100 \times 3 \mathrm{~cm}$ column) using a gradient of ethyl acetate-MeOH (100:0-90:10) to yield three fractions (Fr.1-Fr.3) based on the TLC (thin layer chromatography) profiles. TLC was performed on silica-gel plates with solvent of ethyl acetate/MeoH (4:1). All fractions (Fr.) were screened against $R$. solanacearum. The most active, Fr.1 and Fr.2, were applied to a Sephadex LH-20 column eluted with $\mathrm{CH}_{2} \mathrm{Cl}_{2} / \mathrm{MeOH}(1: 1, v / v)$ and then further purified by semipreparative HPLC (Agilent 1260, Zorbax SB-C18, $5 \mu \mathrm{m}, 250 \times 9.4 \mathrm{~mm}$ inner diameter; $1.5 \mathrm{~mL} / \mathrm{min} ; 220 \mathrm{~nm} ; 254 \mathrm{~nm}$; Agilent, Palo Alto, CA, USA) MeOH/H2O (90:10, v/v) to obtain Compound 1 ( $t R 10.928 \mathrm{~min}, 9.3 \mathrm{mg}$ ) and Compound $2(t R 12.367 \mathrm{~min}, 60.4 \mathrm{mg}$ ). We chose the main product, Compound 2, for further research. NMR spectra (1H and 13C) were measured with a Bruker DRX-400 (400 MHz for ${ }^{1} \mathrm{H}$ and $100 \mathrm{MHz}$ for ${ }^{13} \mathrm{C}$ ) spectrometer (Bruker, Rheinstetten, Germany). The ESI-MS (electrospray ionization mass spectra) spectra were taken on a Q-TOF Micro LC-MS-MS mass spectrometer (Waters Co, Milford, MA, USA).

\subsection{Determination of Minimum Inhibitory Concentration (MIC)}

The minimum inhibitory concentration (MIC) of the antibacterial compounds was determined as described by Rathod et al. [45]. R. solanacearum was grown in BG medium with $0.5 \%$ glucose in shake flasks at $28^{\circ} \mathrm{C}$ for $24 \mathrm{~h}$. Cells were harvested by centrifugation, washed with $0.85 \%$ saline twice, then the supernatant was discarded and $0.85 \%$ saline was added to the washed cells. The suspensions were standardized to an optical density (OD) of 0.2 at $540 \mathrm{~nm}$. Antibacterial compounds were two-fold serially diluted to obtain concentrations ranging from 0.2 to $12.8 \mathrm{mg} \mathrm{L}^{-1}$ and one tube without drug 
served as a control. All of the tubes were inoculated with $1 \mathrm{~mL}$ of suspension of $R$. solanacearum above and incubated at $37^{\circ} \mathrm{C}$ for 12 to $16 \mathrm{~h}$. The turbidity of each tube with respect to the control tube was measured. The MIC value was defined as the lowest concentration of a compound that completely inhibits growth.

\subsection{Biological Assays in Tomato Seedlings}

Germination of tomato seedlings and preparation of bacterial inoculum were prepared as described by Singh et al. [22]. Freshly grown $R$. solanacearum was inoculated into $50 \mathrm{~mL}$ BG media broth with $0.5 \%$ glucose and incubated at $28^{\circ} \mathrm{C}$ and $150 \mathrm{rpm}$ for $24 \mathrm{~h}$. The bacterial cultures were obtained by centrifugation at $4000 \mathrm{rpm}$ and $4{ }^{\circ} \mathrm{C}$ for $15 \mathrm{~min}$ and were then resuspended in an equal volume of sterile distilled water to obtain a concentration of approximately $10^{9} \mathrm{cfu} \mathrm{mL}^{-1}$. Strain NEAU-HV9 was cultured in ISP 2 broth on rotary shaker for 3 days at $28^{\circ} \mathrm{C}$ and centrifuged at 10,000 rpm. Subsequently, cell pellets were diluted in $0.85 \%(w / v) \mathrm{NaCl}$ solution and adjusted to $10^{7}, 10^{8}$ or $10^{9} \mathrm{cfu} \mathrm{mL}^{-1}$. Root inoculation of $R$. solanacearum in tomato seedlings was carried out as described by Singh et al. [22]. About 15 to $20 \mathrm{~mL}$ of $R$. solancearum inoculum was taken in a sterile container. Tomato seedlings (6 to 7 days old) were picked one at a time from the germinated seedling tray and then the roots of each seedling were dipped in the bacterial inoculum (up to the root-shoot junction). Four treatments were established as follows: TR 1 (tomato seedlings were pre-inoculated with suspension $\left(10^{7}, 10^{8}\right.$ or $10^{9} \mathrm{cfu} \mathrm{mL}^{-1}$ ) of strain NEAU-HV9 and then inoculated with R. solanacearum); TR 2 (tomato seedlings were pre-inoculated with $R$. solanacearum and then transferred to microfuge tubes with the addition of 1 to $1.5 \mathrm{~mL}$ of sterile water and active fraction, where the final treatment concentrations were $1 \times$ MIC and $2 \times$ MIC, respectively); CK 1 (tomato seedlings were inoculated with sterile water); and CK 2 (tomato seedlings only were inoculated with $R$. solanacearum). For all of the treatments, the root-dip inoculated seedlings were transferred to an empty $1.5 \mathrm{~mL}$ sterile microfuge tube. After approximately 5 minutes, 1 to $1.5 \mathrm{~mL}$ of sterile water was added to the tube. All the inoculated seedlings, along with the controls, were transferred to a growth chamber maintained at $28{ }^{\circ} \mathrm{C}$ with $75 \%$ relative humidity (RH) and a 12-h photoperiod. Seedlings were analyzed for disease progression after 7 days. Sets of 4 seedlings were recruited in each dilution inoculation, and each assay was performed in triplicate.

\subsection{Pot Culture Experiments}

Prior to use, seed surfaces were disinfected with $2 \%$ sodium hypochlorite for 2 min [46]. Both germination and plant growth conditions followed 75-90\% RH and a 12-h photoperiod at $28{ }^{\circ} \mathrm{C}$. Four treatments were established as follows: TR 1 (one day before transplanting the test plants, strain NEAU-HV9 was added into the sterilized soil so that each gram of soil received about $1 \times 10^{9} \mathrm{cfu} \mathrm{g}^{-1}$ bacterial cells. Seven day old tomato seedlings were transferred to the soil; after three weeks, plants were inoculated with a suspension $\left(\mathrm{OD}_{600}=0.3\right)$ of $R$. solanacearum); TR 2 (seven day old tomato seedlings were transferred to sterilized soil; after three weeks, tomato seedlings were irrigated with a solution of actinomycin $\mathrm{D}\left(0.6 \mathrm{mg} \mathrm{L}^{-1}\right)$. After one day, tomato plants were inoculated with a suspension $\left(\mathrm{OD}_{600}=0.3\right)$ of $R$. solanacearum by pouring it onto the soil of unwounded plants at a final concentration of $1 \times 10^{7} \mathrm{cfu} \mathrm{g}^{-1}$ of soil [47]); CK 1 (seven day old tomato seedlings were transferred to sterilized soil; after three weeks, tomato seedlings were irrigated with sterilized water as positive control); and CK 2 (seven day old tomato seedlings were transferred to sterilized soil; after three weeks, tomato seedlings were inoculated with a suspension $\left(\mathrm{OD}_{600}=0.3\right)$ of $R$. solanacearum as a negative control). All plants were kept in the greenhouse at $24-28{ }^{\circ} \mathrm{C}$ and $75-90 \% \mathrm{RH}$ with a 12-h photoperiod. Treatments were replicated three times with five plants per replication. The disease incidence was rated using the $0-4$ scale [48]. 


\section{Results}

\subsection{Isolation and Identification of an Antimicrobial Compound Producing Strain}

More than 20 isolates from the soil samples were isolated, purified, and screened for bioactivity against $R$. solanacearum. Among them, only four isolates showed bioactivity against $R$. solanacearum . Since the methanol extract of the the cell pellet and supernatant of one isolate, designated as NEAU-HV9, revealed a higher activity $(30.5 \mathrm{~mm}$ and $32.8 \mathrm{~mm})$ against the tested bacterial strain (Table 1, Figure S2), this strain was selected for further studies.

Table 1. Bioactivities of the supernatant and cell pellet of NEAU-HV9 against $R$. solanacearum.

\begin{tabular}{lcc}
\hline & Methanol Extract of Cell Pellet & Supernatant \\
\hline Inhibitory zone diameters $(\mathrm{mm})$ & 30.5 & 32.8 \\
\hline
\end{tabular}

Data shown are the mean of two replications.

Strain NEAU-HV9 was aerobic, Gram-stain positive and formed well-developed, branched substrate hyphae and aerial mycelium that differentiated into spiral spore chains with oval spores (Figure 1). The spore surface was wrinkled. It had good growth on ISP 1, ISP 2, ISP 3, ISP 4, ISP 5, ISP 6, ISP 7, Bennett's agar and Nutrient agar, and poor growth on Czapek's agar (Figure S1). The data on the growth characteristics of NEAU-HV9 in different media are given in Table S1.

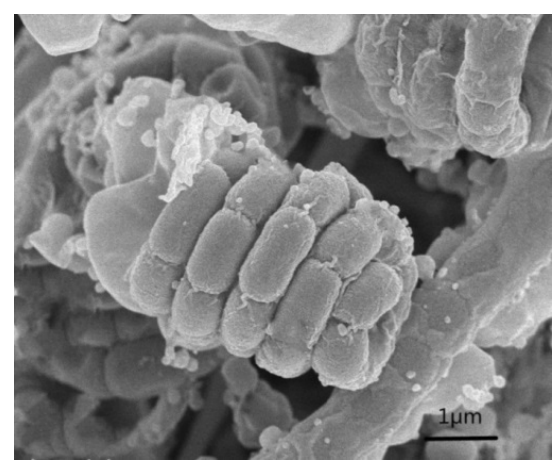

Figure 1. Scanning electron micrograph of strain NEAU-HV9 grown on International Streptomyces Project (ISP) 3 agar for 2 weeks at $28^{\circ} \mathrm{C}$.

Further characterization of NEAU-HV9 was performed by evaluating various biochemical tests (Table S2). Growth at $15{ }^{\circ} \mathrm{C}$ to $37^{\circ} \mathrm{C}$ (optimum: $28^{\circ} \mathrm{C}$ ) and in the range of pH 5 to 9 (optimum: $\mathrm{pH} 7.0)$. Tolerate up to $7 \%(w / v) \mathrm{NaCl}$ in the culture medium. Positive for hydrolysis of starch, production of $\mathrm{H}_{2} \mathrm{~S}$, hydrolysis of aesculin and decomposition of adenine, hypoxanthine, tyrosine and xanthine, negative for reduction of nitrate, coagulation and peptonization of milk, liquefaction of gelatin and decomposition of casein. D-Glucose, D-maltose, D-mannitol, D-galactose, inositol, D-mannose, L-rhamnose and D-sucrose are utilized as sole carbon sources, but not L-arabinose, dulcitol, D-fructose, lactose, D-ribose, D-sorbitol or D-xylose. L-Alanine, D-arginine, L-asparagine, L-aspartic acid, L-glutamic acid, L-glutamine, glycine, L-proline, L-serine, L-threonine and L-tyrosine are utilized as sole nitrogen sources, but not creatine. The above growth data of isolate NEAU-HV9 denote that the isolate has the typical characteristics of the genus Streptomyces.

Recently, it has been suggested that the $16 \mathrm{~S}$ rRNA gene can be used as a reliable molecular clock due to 16S rRNA sequences from distantly related bacterial lineages having similar functionalities [49]. Basically, the 16S rRNA gene sequence, comprising of about 1500 bp with hyper variable and conserved regions, is universal in all bacteria. According to Woese's report [50], comparing a stable part of the genetic code could determine phylogenetic relationships of bacteria. The hyper variable regions of the 16S rRNA gene sequences provide species-specific signature sequences, so it is widely used in 
bacterial identification all over the world. Therefore, the almost-complete $16 \mathrm{~S}$ rRNA gene sequence (1510 bp) of strain NEAU-HV9 was obtained and has been deposited as MN578143 in the GenBank, EMBL (European Molecular Biology Laboratory) and DDBJ (DNA Data Bank of Japan) databases. BLAST sequence analysis of the 16S rRNA gene sequence indicated that strain NEAU-HV9 was related to members of the genus Streptomyces. The EzBioCloud analysis showed that strain NEAU-HV9 was most closely related to Streptomyces panaciradicis $1 \mathrm{MR}-8^{\mathrm{T}}$ and Streptomyces sasae JR-39 ${ }^{\mathrm{T}}$ with a gene sequence similarity of $98.90 \%$ and $98.89 \%$, respectively. In conclusion, based on the $16 \mathrm{~S}$ rRNA gene sequence and the genetic identity of isolate NEAU-HV9, the isolated strain was further identified by neighbor-joining tree (Figure 2), and was also found to belong to the genus Streptomyces.

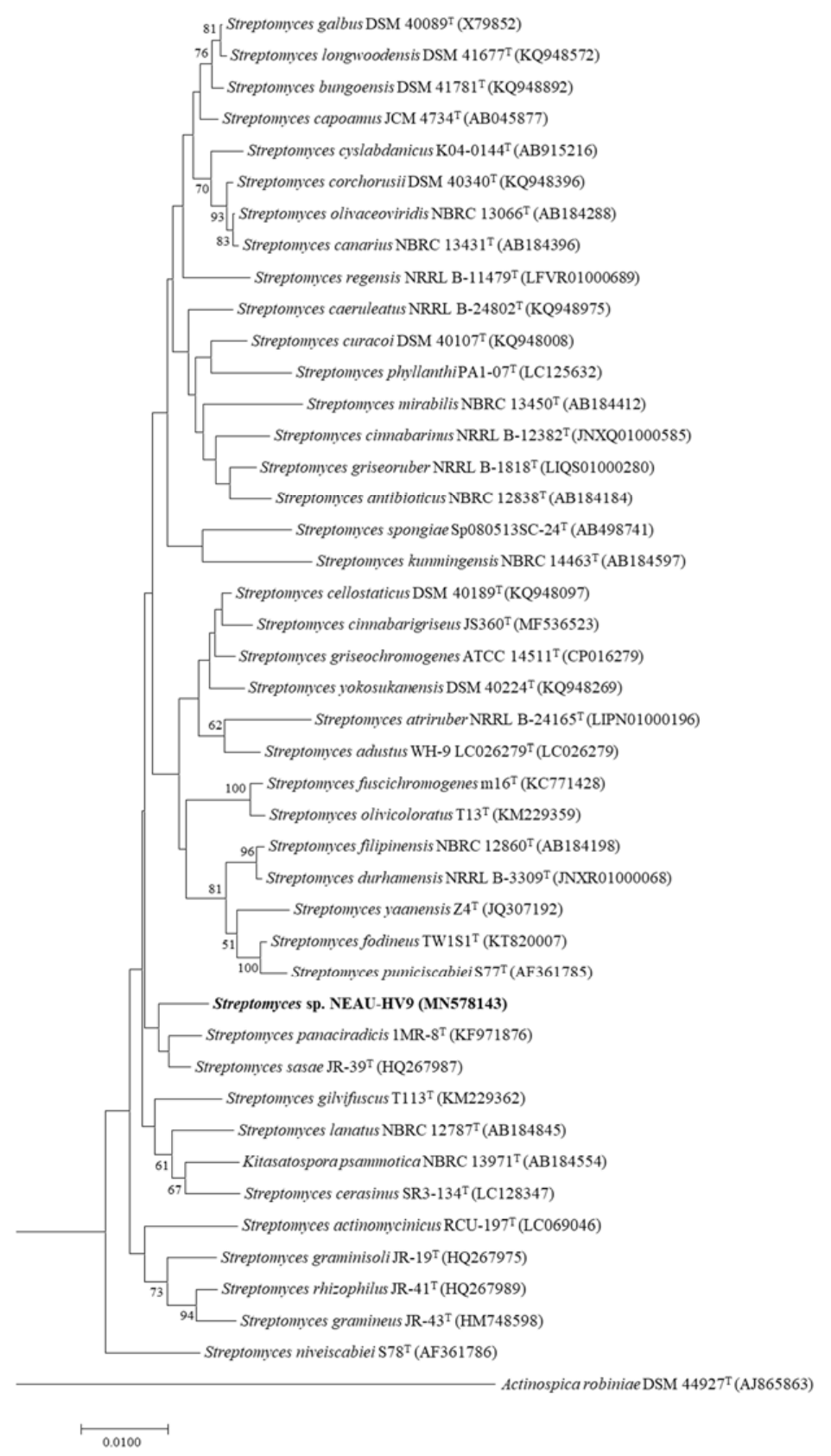

Figure 2. Neighbor-joining phylogenetic tree based on $16 \mathrm{~S}$ rRNA gene sequences showing the relationships among strain NEAU-HV9 (bold) and members of the genus Streptomyces. Bootstrap percentages $(\geq 50 \%)$ based on 1000 resamplings are listed at the nodes. Actinospica robiniae DSM $44927^{\mathrm{T}}$ was used as the out-group. Scale bar represents 0.01 nucleotide substitutions per site. 


\subsection{Structural Characterization of Compound}

The active component was isolated from fermentation medium $(7.5 \mathrm{~L})$ and one bioactive compound was obtained as red, amorphous powder. The compound had UV visible spectra at $215 \mathrm{~nm}, 440 \mathrm{~nm}$ in methanol. The compound showed absorptions at $220 \mathrm{~nm}$ and $254 \mathrm{~nm}$ with a retention time of $12.367 \mathrm{~min}$ (Figure S3), similar to that of actinomycin class of compounds [51,52]. The structure of the compound was further elucidated by ${ }^{1} \mathrm{H} \mathrm{NMR},{ }^{13} \mathrm{C} \mathrm{NMR}$, and MS analysis as well as comparison with previously reported data. The ESI-MS of the isolated compound revealed molecular ion peaks at $\mathrm{m} / \mathrm{z} 1277.6[\mathrm{M}+\mathrm{Na}]^{+}$(Figure S4), which was identical to that of actinomycin D [53]; ${ }^{1} \mathrm{H}$ and ${ }^{13} \mathrm{C}$ spectra of the isolated compound in $\mathrm{CD}_{4} \mathrm{O}$ also showed great similarities to that of actinomycin D [52,53] (Figures S5 and S6). In addition, the retention time of commercial actinomycin D (Biotopped, purity: $\geq 98 \%$ ) was $12.328 \mathrm{~min}$ (Figure S7), and the retention time of compound 2 was $12.367 \mathrm{~min}$ (Figure S3). Compound 2 and commercial actinomycin D have similar activity against $R$. solanacearum (Figure S8). The above results showed that the structure of the main active compound was confirmed to be actinomycin D (Figure 3).

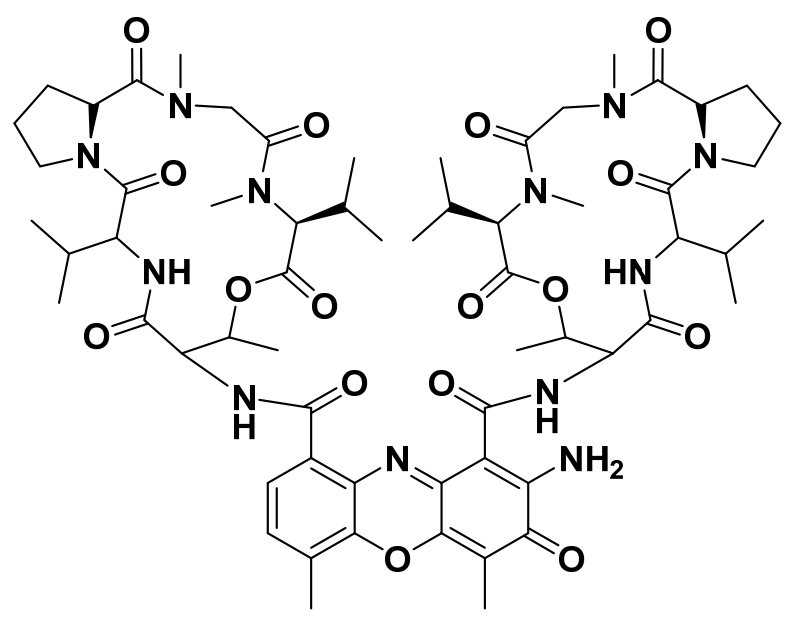

Figure 3. Chemical structure of actinomycin D.

\subsection{Bioactivity of Isolated Compound}

\subsubsection{Minimum Inhibitory Concentration (MIC)}

The minimum inhibitory concentration (MIC) of the antibacterial compound was determined as described by Rathod et al. [45]. The minimum inhibitory concentration of actinomycin D was determined as $0.6 \mathrm{mg} \mathrm{L}^{-1}\left(0.48 \mu \mathrm{mol} \mathrm{L}^{-1}\right)$ against $R$. solanacearum (Table 2).

Table 2. Minimum inhibitory concentration (MIC) values of actinomycin D against $R$. solanacearum.

\begin{tabular}{cc}
\hline Pathogen & MIC $(\mathrm{mg} / \mathrm{L})$ \\
\hline R. solanacearum & $0.6 \pm 0.2$ \\
\hline Data shown are the mean of three replications.
\end{tabular}

\subsubsection{Biological Assays in Tomato Seedlings}

The efficacy of the selected antagonist for the control of $R$. solanacearum was evaluated on tomato seedlings (Figure 4 and Figure S9, Table 3). The disease assessment was carried out using the method described in Kumar [23]. For the plants in the TR 1 group, the $10^{9} \mathrm{cfu} \mathrm{mL}^{-1}$ suspension of NEAU-HV9 was effective against $R$. solanacearum when compared with the control (CK 2); all seedlings were as healthy as the CK 1 group. The $10^{8} \mathrm{cfu} \mathrm{mL}^{-1}$ suspension of NEAU-HV9 showed very weak bioactivity against $R$. solanacearum compared with the control (CK 2); only one seedling was healthy 
and others were wilted. The $10^{7} \mathrm{cfu} \mathrm{\textrm {mL } ^ { - 1 }}$ suspension of NEAU-HV9 exhibited no bioactivity against $R$. solanacearum; all seedlings were wilted, the same as the seedlings that were dried.
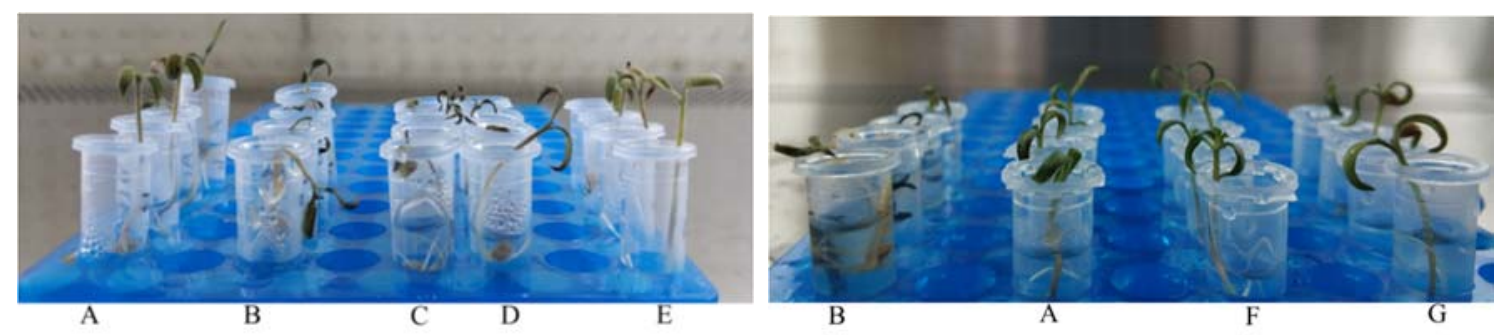

Figure 4. Control efficiency of strain NEAU-HV9 against $R$. solanacearum. A, tomato seedlings were inoculated with sterile water (CK 1); B, tomato seedlings only were inoculated with $R$. solanacearum (CK 2); C, tomato seedlings were pre-inoculated with suspension $\left(10^{7} \mathrm{cfu} \mathrm{mL}^{-1}\right)$ of NEAU-HV9 and then inoculated with $R$. solanacearum (TR 1); D, tomato seedlings were pre-inoculated with suspension $\left(10^{8} \mathrm{cfu} \mathrm{mL}^{-1}\right)$ of NEAU-HV9 and then inoculated with $R$. solanacearum (TR 1); E, tomato seedlings were pre-inoculated with suspension $\left(10^{9} \mathrm{cfu} \mathrm{mL}^{-1}\right)$ of NEAU-HV9 and then inoculated with $R$. solanacearum (TR 1); F, actinomycin D at the concentration $1 \times$ MIC (TR 2); G, actinomycin D at the concentration $2 \times$ MIC (TR 2).

Table 3. Effect of the strain NEAU-HV9 and actinomycin D on the incidence and control of tomato bacterial wilt in tomato seedlings.

\begin{tabular}{ccc}
\hline Treatment & Wilt Incidence (\%) & Control Efficacy (\%) \\
\hline NEAU-HV9 $\left(10^{7} \mathrm{cfu} \mathrm{mL}^{-1}\right)$ & $100 \pm 0^{\mathrm{a}}$ & $0 \pm 0^{\mathrm{a}}$ \\
NEAU-HV9 $\left(10^{8} \mathrm{cfu} \mathrm{mL}^{-1}\right)$ & $93 \pm 11.6^{\mathrm{b}}$ & $6.6 \pm 11.5^{\mathrm{b}}$ \\
NEAU-HV9 $\left(10^{9} \mathrm{cfu} \mathrm{mL}^{-1}\right)$ & $0 \pm 0^{\mathrm{c}}$ & $100 \pm 0^{\mathrm{c}}$ \\
Actinomycin D $(1 \times \mathrm{MIC})$ & $0 \pm 0^{\mathrm{c}}$ & $100 \pm 0^{\mathrm{c}}$ \\
Actinomycin D $(2 \times \mathrm{MIC})$ & $0 \pm 0^{\mathrm{c}}$ & $100 \pm 0^{\mathrm{c}}$ \\
Control & $100 \pm 0^{\mathrm{a}}$ & $\ldots$ \\
\hline
\end{tabular}

Data shown are the mean of three replications. Means within the same column followed by the same letter are not significantly different $(p=0.05)$ according to Fisher's least significant difference test.

Actinomycin D was highly effective against $R$. solanacearum in tomato seedlings (Figure 4 and Figure S9, Table 3). It was notable that all seedlings of the control (CK 2) were wilted, however after treatment with actinomycin D at the concentration $1 \times \mathrm{MIC}$ and $2 \times \mathrm{MIC}$, none of the seedlings exhibited disease symptoms; the control efficacy of the formulation was $100 \%$.

\subsection{Pot Culture Experiments}

In the pot culture experiments, NEAU-HV9 and actinomycin D effectively suppressed the development of bacterial wilt caused by R. solanacearum (Table 4, Figure S10). The negative control treatment had $73.9 \%$ relative disease incidence. For strain NEAU-HV9 and actinomycin D, the control efficacies of the formulations were $82 \%$ and $100 \%$, respectively.

Table 4. Effect of the strain NEAU-HV9 and actinomycin D on the incidence and control of tomato bacterial wilt in pot culture experiments.

\begin{tabular}{ccc}
\hline Treatment & Wilt Incidence (\%) & Control Efficacy (\%) \\
\hline NEAU-HV9 & $13.3 \pm 5.8^{\mathrm{b}}$ & $82 \pm 6^{\mathrm{a}}$ \\
Actinomycin D & $0 \pm 00^{\mathrm{b}}$ & $100 \pm 0^{\mathrm{a}}$ \\
Control & $73.9 \pm 6.6^{\mathrm{a}}$ & \\
\hline
\end{tabular}

Wilt incidence (WI) was calculated as the percentage of leaves that were completely wilted. Control efficacy was calculated using the following formula: control efficacy $(\%)=100 \times($ WI of control - WI of treatment)/WI of control. Data shown are the mean of three replications. Means within the same column followed by the same letter are not significantly different $(p=0.05)$ according to Fisher's least significant difference test. 


\section{Discussion}

Soil-borne diseases have caused a significant decline in yield in the monoculture tomato field [3]. Ralstonia solanacearum is an important soil-borne bacterial plant pathogen which is distributed all over the world [5]. Recently, the biological control of soil-borne diseases has attracted more attention due to its environmental friendliness and high efficiency [54]. Therefore, isolation, screening and application of highly efficient antagonistic microorganisms is a key factor in biological control. With this outlook, a Streptomyces sp. strain NEAU-HV9 was isolated and found to exhibit antibacterial activities against $R$. solanacearum in the present study. By using $16 \mathrm{~S}$ rRNA gene sequence analysis, combined with morphological, cultural and physiological characteristics, the results showed that strain NEAU-HV9 belongs to members of the genus Streptomyces and was most closely related to Streptomyces panaciradicis $1 \mathrm{MR}-8^{\mathrm{T}}$ and Streptomyces sasae JR-39 ${ }^{\mathrm{T}}$ with gene sequence similarities of $98.90 \%$ and $98.89 \%$, respectively.

Actinobacteria, particularly Streptomyces, are ubiquitous in the rhizosphere soil and can protect plant from pathogenic fungi/bacteria [55], so they have always been used in agriculture [56]. For instance, several Streptomyces species such as strains CAI-24, CAI-121, CAI-127, KAI-32 and KAI-90 have been used as BCAs against Fusarium wilt in chickpea plants [57]. The Streptomyces sp. CB-75, selected from banana rhizosphere soil, showed antifungal activity against 11 plant pathogenic fungi [54]. In this study, the Streptomyces sp. NEAU-HV9 exhibited strong antagonistic activity against $R$. solanacearum. According to the study of Singh et al., susceptibility of early stages of tomato seedlings toward the pathogen was confirmed by root-inoculation of R. solanacearum in early stages of tomato seedlings [22]. The antagonistic strains should reach a certain amount to demonstrate a significant biocontrol effect $[58,59]$. In this study, we inoculated very high numbers of $R$. solanacearum and very high levels of Streptomyces sp. NEAU-HV9 $\left(10^{9} \mathrm{cfu} \mathrm{mL}^{-1}\right)$ in small tubes in the TR 1 group. After culturing for seven days, all tomato seedlings were as healthy as the CK 1 control group (Table 3). There are only R. solanacearum and Streptomyces sp. NEAU-HV9 in this artificial system, which can better prove that a single NEAU-HV9 was able to be effective against $R$. solanacearum. On the seventh day, more than $90 \%$ of seedlings inoculated with $R$. solanacearum were found to be killed, but water-inoculated control seedlings were not wilted/dried [23]. Freshly grown tomato seedlings are too small to carry out detailed disease assessment, and can only be described as healthy, healthy wilted or dried. In the tests of this study, tomato seedlings inoculated with suspension $\left(10^{7}\right.$ or $\left.10^{8} \mathrm{cfu} \mathrm{mL}{ }^{-1}\right)$ of NEAU-HV9 and $R$. solanacearum showed healthy wilted and dried disease phenotypes at different levels, while all tomato seedlings inoculated with suspension $\left(10^{9} \mathrm{cfu} \mathrm{mL}{ }^{-1}\right)$ of NEAU-HV9 and R. solanacearum were healthy (Figure 4). The results indicated that there are only R. solanacearum and Streptomyces sp. NEAU-HV9 in this artificial system, which can better prove that a single NEAU-HV9 was able to be effective against $R$. solanacearum. In addition, strain NEAU-HV9 effectively controlled $R$. solanacearum on larger plants in pot culture experiments (Table 4). Thus, the test presented in this study is viable for a preliminary screening of antagonistic actinobacterial strains against $R$. solanacearum and has important aspects with respect to reduced time, space consumption and economics. Meanwhile, the results showed the possibility of using Streptomyces sp. NEAU-HV9 as bioinoculant for R. solanacearum.

A wide range of bioactive secondary metabolites with anti-inflammatory, antibacterial, antifungal, antialgal, antimalarial and anticancer activities were produced by actinomycetes. Actinomycetes have produced about two-thirds of available antibiotics that have great practical value $[60,61]$. For example, Streptomyces TP-A0595 produced an antagonist that was determined as 6-prenylindole and effective against Alternaria brassicicola by inhibiting the formation of infection hyphae [62]. Streptomyces griseus H7602 produced a monomer compound that has suppressive effect on infection by Phytophthora capsici [63]. Some well-known antibiotics have been isolated from Streptomyces and used as fungicides. Many types of antibiotics with high antibacterial activity were produced from Streptomyces spectabilis, including streptovaricin [64], desertomycin [65] and spectinomycin [66], and they have high application value in the pharmaceutical industry [67]. Actinomycin D (or Dactinomycin) is a proverbial antitumor-antibiotic drug, which belongs to the actinomycin family and was isolated from Streptomyces. Actinomycin D has been demonstrated to have various biological activities. 
Gram-negative bacteria were largely inhibited by using 10-100 mg per liter concentrations [68]. Actinomycin D produced by the bacterium Streptomyces hydrogenans IB310 was effective against both bacterial and fungal phytopathogens [51], and the authors proposed that actinomycin D might be developed as an antibacterial agent used in agriculture. However, there are no reports on antibacterial activities against $R$. solanacearum and it is not currently used in agriculture. In this study, Streptomyces sp. NEAU-HV9, which showed strong antibacterial activity against $R$. solanacearum, was isolated and identified. To learn more about the chemical nature of the antibacterial activity of the culture filtrate, the active compound actinomycin D was finally obtained. In this paper, we tested the in vitro antibacterial activity of actinomycin $D$ against $R$. solanacearum and obtained a MIC value of $0.6 \mathrm{mg} \mathrm{L}^{-1}\left(0.48 \mu \mathrm{mol} \mathrm{L}^{-1}\right)$, which was many fold lower than other reported new natural antibacterial agents [69], synthesized antibacterial agents and those of commercial fungicides including gentamicin and streptomycin [70]. The antibacterial activity of actinomycin D against $R$. solanacearum tomato seedlings treated with $1 \times$ MIC and $2 \times$ MIC were determined. None of the seedlings inoculated with actinomycin D exhibited disease symptoms and the phytotoxic rating of actinomycin D was similar to that of a water control. Thus, actinomycin $\mathrm{D}$ was not phytotoxic at a concentration of $0.6 \mathrm{mg} \mathrm{L}^{-1}$ $\left(0.48 \mu \mathrm{mol} \mathrm{L}^{-1}\right)$. The results suggest that actinomycin D might be useful as a candidate pesticide for the treatment of Ralstonia solanacearum in tomato.

\section{Conclusions}

In summary, this study found that Streptomyces sp. NEAU-HV9 exerted significant antibacterial activity against $R$. solanacearum, and actinomycin D, which was produced by Streptomyces sp. NEAU-HV9, exhibited a minimum inhibitory concentration (MIC) against $R$. solanacearum of $0.6 \mathrm{mg} \mathrm{L}^{-1}$ $\left(0.48 \mu \mathrm{mol} \mathrm{L}{ }^{-1}\right)$. In addition, Streptomyces sp. NEAU-HV9 and actinomycin D can effectively inhibit the occurrence of $R$. solanacearum. From the results, it is obvious that Streptomyces sp. NEAU-HV9 is an important microbial resource as a biological control against $R$. solanacearum and actinomycin $\mathrm{D}$ is a promising candidate for the development of potential antibacterial biocontrol agents.

Supplementary Materials: The following are available online at http://www.mdpi.com/2076-2607/8/3/351/s1: Table S1: Growth and cultural characteristics of strain NEAU-HV9 after 2 weeks at $28{ }^{\circ} \mathrm{C}$; Table S2: Physiological and biochemical characteristics of strain NEAU-HV9; Figure S1: Cultural characteristics of strain NEAU-HV9 observed on ISP 1, ISP 2, ISP 3, ISP 4, ISP 5, ISP6, ISP7, Nutrient agar, Bennett's agar and Czapek's agar after being incubated at $28^{\circ} \mathrm{C}$ for 2 weeks; Figure S2: Bioactivities of the supernatant and cell pellet of NEAU-HV9 against $R$. solanacearum; Figure S3: The HPLC profiles of crude extract produced by Streptomyces NEAU-HV9; Figure S4: Mass Spectrometry of actinomycin D $\left(\mathrm{C}_{62} \mathrm{H}_{86} \mathrm{~N}_{12} \mathrm{O}_{16} \mathrm{Na}\right.$ : 1277.6); Figure S5: ${ }^{1} \mathrm{H}$ NMR of actinomycin D; Figure S6: ${ }^{13} \mathrm{C}$ NMR of actinomycin D; Figure S7: The HPLC profiles of commercial actinomycin D; Figure S8: Bioactivities of commercial actinomycin D and the main product of NEAU-HV9 against R. solanacearum; Figure S9: Control efficiency of strain NEAU-HV9 against $R$. solanacearum; Figure S10: Control efficiency of the actinomycin D and strain NEAU-HV9 against $R$. solanacearum.

Author Contributions: L.L., X.H., X.L., H.W. and Y.W. performed the experiments. X.Z., L.Z. and P.C. analyzed the data. L.L. wrote the paper. X.W. and X.H. prepared the figures and tables. J.Z. and W.X. designed the experiments and reviewed the manuscript. All authors have read and agreed to the published version of the manuscript.

Funding: This work was supported in part by grants from the National Natural Youth Science Foundation of China (No. 31701858), the China Postdoctoral Science Foundation (2018M631907), the Heilongiiang Postdoctoral Fund (LBH-Z17015), the University Nursing Program for Young Scholars with Creative Talents in Heilongjiang Province (UNPYSCT-2017017) and the "Young Talents" Project of Northeast Agricultural University (17QC14).

Conflicts of Interest: The authors declare that there are no conflicts of interest. 


\section{References}

1. Lee, C.G.; Lida, T.; Uwagaki, Y.; Otani, Y.; Nakaho, K.; Ohkuma, M. Comparison of prokaryotic and eukaryotic communities in soil samples with and without tomato bacterial wilt collected from different fields. Microbes Eniviron. 2017, 32, 376-385. [CrossRef] [PubMed]

2. Singh, V.K.; Singh, A.K.; Kumar, A. Disease management of tomato through PGPB: Current trends and future perspective. 3Biotech 2017, 7, 255. [CrossRef] [PubMed]

3. Zhou, X.G.; Wu, F.Z. Dynamics of the diversity of fungal and Fusarium communities during continuous cropping of cucumber in the green house. FEMS Microbiol. Ecol. 2012, 802, 469-478. [CrossRef] [PubMed]

4. Yabuuchi, E.; Kosako, Y.; Yano, I.; Hota, H.; Nishiuchi, Y. Transfer of two Burkholderia and an Alcaligenes species to Ralstonia gen. nov., Ralstonia solanacearum (Smith, 1986) comb. nov. Microbiol. Immun. 1995, 39, 897-904. [CrossRef]

5. Hayward, A.C. Biology and epidemiology of bacterial wilt caused by Pseudomonas solanacearum. Ann. Rev. Phytopathol. 1991, 29, 65-87. [CrossRef]

6. Vu, T.T.; Kim, J.C.; Choi, Y.H.; Choi, G.J.; Jang, K.S.; Choi, T.H.; Yoon, T.M.; Lee, S.W. Effect of Gallotannins Derived from Sedum takesimense on Tomato Bacterial Wilt. Plant Dis. 2013, 97, 1593-1598. [CrossRef]

7. Genin, S.; Boucher, C. Lessons learned from the genome analysis of Ralstonia solanacearum. Ann. Rev. Phytopathol. 2004, 42, 107-134. [CrossRef]

8. Ciampi-Panno, L.; Fernandez, C.; Bustamante, P.; Andrade, N.; Ojeda, S.; Conteras, A. Biological control of bacterial wilt of potatoes caused by Pseudomonas solanacearum. Am. Potato J. 1989, 66, 315-332. [CrossRef]

9. McLaughlin, R.J.; Sequeira, L.; Weingartner, D.P. Biocontrol of bacterial wilt of potato with an avirulent strain of Pseudomonas solanacearum: Interactions with root-knot nematodes. Am. Potato J. 1990, 67, 93-107. [CrossRef]

10. Toyota, K.; Kimura, M. Suppresision of Ralstonia solanacearum in soil following colonization by other strains of $R$. solanacearum. Soil Sci. Plant Nutr. 2000, 46, 449-459.

11. Viaene, T.; Langendries, S.; Beirinckx, S.; Maes, M.; Goormachtig, S. Streptomyces as a plant's best friend? FEMS Microbiol. Ecol. 2016, 92. [CrossRef] [PubMed]

12. Dias, M.P.; Bastos, M.S.; Xavier, V.B.; Cassel, E.; Astarita, L.V.; Santarémm, E.R. Plant growth and resistance promoted by Streptomyces spp. in tomato. Plant Physiol. Biochem. 2017, 118, 479-493. [CrossRef] [PubMed]

13. Xio, K.; Kinkel, L.L.; Samac, D.A. Biological control of Phytophthora root rots on alfalfa and soybean with Streptomyces. Biol. Control 2002, 23, 285-295. [CrossRef]

14. El-Tarabily, K.A.; Sivasithamparam, K. Non-streptomycete Actinobacteria as biocontrol agents of soil-borne fungal plant pathogens and as plant growth promoters. Soil Biol. Biochem. 2006, 38, 1505-1520. [CrossRef]

15. Taechowisan, T.; Chuaychot, N.; Chanaphat, S.; Wanbanjob, A.; Tantiwachwutikul, P. Antagonistic effects of Streptomyces sp. SRM1 on colletotrichum musae. Biotechnology 2009, 8, 86-92. [CrossRef]

16. Bentley, S.D.; Chater, K.F.; Cerden, A.M.; Challis, G.L.; Thomson, N.R.; James, K.D.; Harris, D.E.; Quail, M.A.; Kieser, H.; Harper, D.; et al. Complete genome sequence of the model actinomycete Streptomyces coelicolor A3. Nature 2002, 417, 141-147. [CrossRef]

17. Brockmann, H. Die actinomycine. Angew. Chem. 1960, 87, 1767-1947.

18. Farber, S.; D’Angio, G.; Evans, A.; Mitus, A. Clinical studies of actinomycin D with special reference to Wilms' tumor in children. J. Urol. 2002, 168, 2560-2562. [CrossRef]

19. Womer, R.B. Soft tissue sarcomas. Eur. J. Cancer 1997, 33, 2230-2234. [CrossRef]

20. Monteiro, F.; Genin, S.; van, D.I.; Valls, M. A luminescent reporter evidences active expression of Ralstonia solanacearum type III secretion system genes throughout plant infection. Microbiology 2012, 158, 2107-2116. [CrossRef]

21. Guidot, A.; Jiang, W.; Ferdy, J.B.; Thébaud, C.; Barberis, P.; Gouzy, J.; Genin, S. Multihost experimental evolution of the pathogen Ralstonia solanacearum unveils genes involved in adaptation to plants. Mol. Biol. Evol. 2014, 11, 2913-2928. [CrossRef] [PubMed]

22. Singh, N.; Phukan, T.; Sharma, P.L.; Kabyashree, K.; Barman, A.; Kumar, R.; Sonti, R.V.; Genin, S.; Ray, S.K. An Innovative Root Inoculation Method to Study Ralstonia solanacearum Pathogenicity in Tomato Seedlings. Phytopathology 2018, 108, 436-442. [CrossRef]

23. Kumar, R. Studying Virulence Functions of Ralstonia solanacearum, the Causal Agent of Bacterial Wilt in Plants. Ph.D. Thesis, Tezpur University, Tezpur, India, 2014. 
24. van Elsas, J.D.; Kastelein, P.; de Vries, P.M.; van Overbeek, L.S. Effects of ecological factors on the survival and physiology of Ralstonia solanacearum bv 2 in irrigation water. Can. J. Microbiol. 2001, 47, 842-854. [CrossRef] [PubMed]

25. Hayakawa, M.; Nonomura, H. Humic acid-vitamin agar, a new medium for selective isolation of soil actinomycetes. J. Ferment. Technol. 1987, 65, 501-509. [CrossRef]

26. Shirling, E.B.; Gottlieb, D. Methods for characterization of Streptomyces species. Int. J. Syst. Bacteriol. 1966, 16, 313-340. [CrossRef]

27. Zhang, D.C.; Brouchkov, A.; Griva, G.; Schinner, F.; Margesin, R. Isolation and characterization of bacteria from ancient siberian permafrost sediment. Biology 2013, 2, 85-106. [CrossRef]

28. Fu, Y.S.; Yan, R.; Liu, D.; Zhao, J.W.; Song, J.; Wang, X.J.; Cui, L.; Zhang, J.; Xiang, W.S. Characterization of Sinomonas gamaensis sp. nov., a Novel Soil Bacterium with Antifungal Activity against Exserohilum turcicum. Microorganisms 2019, 7, 170. [CrossRef] [PubMed]

29. Gao, F.; Wu, Y.; Wang, M. Identification and antifungal activity of an actinomycete strain against Alternaria spp. Span. J. Agric. Res. 2014, 12, 1158-1165. [CrossRef]

30. Jin, L.Y.; Zhao, Y.; Song, W.; Duan, L.P.; Jiang, S.W.; Wang, X.J.; Zhao, J.W.; Xiang, W.S. Streptomyces inhibens sp. nov., a novel actinomycete isolated from rhizosphere soil of wheat (Triticum aestivum L.). Int. J. Syst. Evol. Microbiol. 2019, 69, 688-695. [CrossRef]

31. Waksman, S.A. The Actinomycetes. A Summary of Current Knowledge; Ronald: New York, NY, USA, 1967.

32. Jones, K.L. Fresh isolates of actinomycetes in which the presence of sporogenous aerial mycelia is a fluctuating characteristic. J. Bacteriol. 1949, 57, 141-145. [CrossRef]

33. Waksman, S.A. Classification, identification and descriptions of genera and species. In The Actinomycetes; Williams and Wilkins: Baltimore, MD, USA, 1961; Volume 2.

34. Kelly, K.L. Inter-Society Color Council-National Bureau of Standards Color-Name Charts Illustrated with Centroid Colors; Government Printing Office: Washington, DC, USA, 1964.

35. Zhao, J.W.; Han, L.Y.; Yu, M.Y.; Cao, P.; Li, D.M.; Guo, X.W.; Liu, Y.Q.; Wang, X.J.; Xiang, W.S. Characterization of Streptomyces sporangiiformans sp. nov., a Novel Soil Actinomycete with Antibacterial Activity against Ralstonia solanacearum. Microorganisms. 2019, 7, 360. [CrossRef] [PubMed]

36. Gordon, R.E.; Barnett, D.A.; Handerhan, J.E.; Pang, C. Nocardia coeliaca, Nocardia autotrophica, and the nocardin strain. Int. J. Syst. Bacteriol. 1974, 24, 54-63. [CrossRef]

37. Yokota, A.; Tamura, T.; Hasegawa, T.; Huang, L.H. Catenuloplanes japonicas gen. nov., sp. nov., nom. rev., a new genus of the order Actinomycetales. Int. J. Syst. Bacteriol. 1993, 43, 805-812. [CrossRef]

38. Woese, C.R.; Gutell, R.; Gupta, R.; Noller, H.F. Detailed analysis of the higher-order structure of 16S-like ribosomal ribonucleic acids. Microbiol. Rev. 1983, 47, 621-669. [CrossRef] [PubMed]

39. Springer, N.; Ludwig, W.; Amann, R.; Schmidt, H.J.; Görtz, H.D.; Schleifer, K.H. Occurrence of fragmented 16S rRNA in an obligate bacterial endosymbiont of Paramecium caudatum. Proc. Natl. Acad. Sci. USA 1993, 90, 9892-9895. [CrossRef]

40. Yoon, S.H.; Ha, S.M.; Kwon, S.; Lim, J.; Kim, Y.; Seo, H.; Chun, J. Introducing EzBioCloud: A taxonomically united database of 16S rRNA and whole genome assemblies. Int. J. Syst. Evol. Microbiol. 2017, 67, 1613-1617. [CrossRef]

41. Saitou, N.; Nei, M. The neighbor-joining method: A new method for reconstructing phylogenetic trees. Mol. Biol. Evol. 1987, 4, 406-425.

42. Kumar, S.; Stecher, G.; Tamura, K. Mega7: Molecular evolutionary genetics analysis version 7.0 for bigger datasets. Mol. Biol. Evol. 2016, 33, 1870-1874. [CrossRef]

43. Felsenstein, J. Confidence limits on phylogenies: An approach using the bootstrap. Evolution 1985, 39, 783-791. [CrossRef]

44. Kimura, M. A simple method for estimating evolutionary rates of base substitutions through comparative studies of nucleotide sequences. J. Mol. Evol. 1980, 16, 111-120. [CrossRef] [PubMed]

45. Rathod, B.B.; Korasapati, R.; Sripadi, P.; Reddy, S.P. Novel actinomycin group compound from newly isolated Streptomyces sp. RAB12: Isolation, characterization, and evaluation of antimicrobial potential. Appl. Microbiol. Biotechnol. 2018, 102, 1241-1250. [CrossRef]

46. Guo, J.H.; Qi, H.Y.; Guo, Y.H.; Ge, H.; Gong, L.Y.; Zhang, L.X.; Sun, P.H. Biocontrol of tomato wilt by growth-promoting rhizobacteria. Biol. Control 2004, 29, 66-72. [CrossRef] 
47. Roy, N.; Choi, K.; Khan, R.; Lee, S.W. Culturing Simpler and Bacterial Wilt Suppressive Microbial Communities from Tomato Rhizosphere. Plant Pathol. J. 2019, 35, 362-371. [PubMed]

48. Roberts, D.P.; Denny, T.P.; Schell, M.A. Cloning of the egl gene of Pseudomonas solanacearum and analysis of its role in phytopathogenicity. J. Bacteriol. 1988, 170, 1445-1451. [CrossRef] [PubMed]

49. Tsukuda, M.; Kitahara, K.; Miyazaki, K. Comparative RNA function analysis reveals high functional similarity between distantly related bacterial 16 S rRNAs. Sci. Rep. 2017, 7, 9993. [CrossRef]

50. Woese, C.R. Bacterial evolution. Microbiol. Rev. 1987, 51, 221-2711. [CrossRef]

51. Kulkarni, M.; Gorthi, S.; Banerjee, G.; Chattopadhyay, P. Production, characterization and optimization of actinomycin D from Streptomyces hydrogenans IB310, a(n antagonistic bacterium against phytopathogens. Biocatal. Agric. Biotechnol. 2017, 10, 69-74. [CrossRef]

52. Zhang, L.L.; Wan, C.X.; Luo, X.X.; Lv, L.L.; Wang, X.P.; Xia, Z.F. Manufacture of Actinomycin D with Streptomyces mutabilis for Controlling Plant Pathogenic Bacteria, Cow Mastitis, and Female Colpitis. China Patent CN104450580A, 25 March 2015.

53. Chen, C.; Song, F.; Wang, Q.; Abdel-Mageed, W.M.; Guo, H.; Fu, C.; Hou, W.; Dai, H.; Liu, X.; Yang, N.; et al. A marine-derived Streptomyces sp. MS449 produces high yield of actinomycin X2 and actinomycin D with potent anti-tuberculosis activity. Appl. Microbiol. Biotechnol. 2012, 95, 919-927. [CrossRef]

54. Chen, Y.F.; Zhou, D.B.; Qi, D.F.; Gao, Z.F.; Xie, J.H.; Luo, Y.P. Growth promotion and disease suppression ability of a streptomyces sp. CB-75 from banana rhizosphere soil. Front. Microbiol. 2018, 8, 2704. [CrossRef]

55. Crawford, D.L.; Lynch, J.M.; Whipps, J.M.; Ousley, M.A. Isolation and characterization of actionomycete antagonists of a fungal root pathogen. Appl. Environ. Microb. 1993, 59, 3889-3905. [CrossRef]

56. Gao, L.; Qiu, Z.; You, J.; Tan, H.; Zhou, S. Isolation and characterization of endophytic Streptomyces strains from surface-sterilized tomato (Lycopersicon esculentum) roots. Lett. Appl. Microbiol. 2004, 39, 425-430.

57. Gopalakrishnan, S.; Pande, S.; Sharma, M.; Humayun, P.; Kiran, B.K.; Sandeep, D.; Vidya, M.S.; Deepthi, K.; Rupela, O. Evaluation of actinomycete isolates obtained from herbal vermicompost for biological control of Fusarium wilt of chickpea. Crop Protect. 2011, 30, 1070-1078. [CrossRef]

58. Bull, C.T. Relationship between root colonization and suppression of Gaeumannomyces graminis var tritici by Pseudomonas fluorescens strain 2-79. Phytopathology 1991, 81, 954-959. [CrossRef]

59. Raaijmakers, J.M.; Leeman, M.; van Oorschot, M.M.P.; van der Sluis, I.; Schippers, B.; Bakker, P.A.H.M. Dose-response relationships in biological-control of Fusarium-wilt of radish by Pseudomonas spp. Phytopathology 1995, 85, 1075-1081. [CrossRef]

60. Wang, J.J.; Zhao, Y.; Ruan, Y.Z. Effects of bio-organic fertilizers produced by four Bacillus amyloliquefaciens strains on banana Fusarium wilt Disease. Compost Sci. Util. 2015, 23, 185-198. [CrossRef]

61. Hong, K.; Gao, A.H.; Xie, Q.Y.; Gao, H.; Zhuang, L.; Lin, H.P.; Yu, H.P.; Li, J.; Yao, X.S.; Goodfellow, M.; et al. Actino-mycetes for marine drug discovery isolated from man-grove soils and plants in China. Mar. Drugs 2009, 7, 24-44. [CrossRef]

62. Sasaki, T.; Igarashi, Y.; Ogawa, M.; Furumai, T. Identification of 6-prenylindole as an antifungal metabolite of Streptomyces sp. TP-A0595 and synthesis and bioactivity of 6-substituted indoles. J. Antibiot. 2002, 55, 1009-1012. [CrossRef] [PubMed]

63. Nguyen, X.H.; Naing, K.W.; Lee, Y.S.; Kim, Y.H.; Moon, J.H.; Kim, K.Y. Antagonism of antifungal metabolites from Streptomyces griseus H7602 against Phytophthora capsici. J. Basic Microbiol. 2015, 55, 45-53. [CrossRef] [PubMed]

64. Kakinuma, K.; Hanson, C.A.; Rinehart, K.L., Jr. Spectinabilin, a new nitro-containing metabolite isolated from Streptomyces spectabilis. Tetrahedron 1976, 32, 217-222. [CrossRef]

65. Ivanova, V. New macrolactone of the desertomycin family from Streptomyces spectabilis. Prep. Biochem. Biotechnol. 1997, 27, 19-38. [CrossRef]

66. Kim, K.R.; Kim, T.J.; Suh, J.W. The gene cluster for spectinomycin biosynthesis and the aminoglycosideresistance function of spcm in Streptomyces spectabilis. Curr. Microbiol. 2008, 57, 371-374. [CrossRef] [PubMed]

67. Selvakumar, J.; Chandrasekaran, S.; Vaithilingam, M. Bio prospecting of marine-derived Streptomyces spectabilis VITJS10 and exploring its cytotoxicity against human liver cancer celllines. Pharmacogn. Mag. 2015, 11, 469-473.

68. Waksman, S.A.; Woodruff, H.B. Bacteriostatic and bactericidal substances produced by a soil actinomyces. Proc. Soc. Exp. Biol. Med. 1940, 45, 609-614. [CrossRef] 
69. Vu, T.T.; Kim, H.; Tran, V.K.; Vu, H.D.; Hoang, T.X.; Han, J.W.; Choi, Y.H.; Jang, K.S.; Choi, G.J.; Kim, J.J. Antibacterial activity of tannins isolated from Sapium baccatum extract and use for control of tomato bacterial wilt. PLOS ONE 2017, 12, e0181499. [CrossRef]

70. Zheng, S.J.; Zhu, R.; Tang, B.; Chen, L.Z.; Bai, H.J.; Zhang, J.W. Synthesis and biological evaluations of a series of calycanthaceous analogues as antifungal agents. Nat. Prod. Res. 2019, 1-9. [CrossRef] [PubMed]

(C) 2020 by the authors. Licensee MDPI, Basel, Switzerland. This article is an open access article distributed under the terms and conditions of the Creative Commons Attribution (CC BY) license (http://creativecommons.org/licenses/by/4.0/). 